\title{
Brexit's Protectionist Policy and Implications for the British Pound
}

\author{
Lara Joy Dixon ${ }^{1} \&$ Hoje Jo ${ }^{1}$ \\ ${ }^{1}$ Santa Clara University, Santa Clara, USA \\ Correspondence: Hoje Jo, Santa Clara University, Santa Clara, CA 95053, USA.
}

Received: August 2, 2017

Accepted: August 21, $2017 \quad$ Online Published: September 11, 2017

doi:10.5430/ijfr.v8n4p7

URL: https://doi.org/10.5430/ijfr.v8n4p7

\begin{abstract}
In this paper, we examine the association among the macroeconomic variables - interest rate, inflation rate, unemployment, and the expected spot rate of the British pound with respect to the Euro around the announcement of "Brexit", June 2016, using the two international parity relationships, Purchase Power Parity (PPP) and International Fisher effect (IFE). We use the two international parity relationships to examine the significance of change in daily interest rates and monthly inflation rates on the change in actual daily spot rates. In addition, we postulate that the protectionist nature of Brexit policy has contributed to lowering U.K. unemployment and prompted wage growth, resulting in higher inflation rates. Our analysis, examining both the magnitude and directional deviation of the actual spot rate compared to the spot rate using the two parity relations, indicate that spot rates predicted based on the PPP and the IFE relations suggest the weakening of the British pound after the Brexit announcement. Furthermore, we find that U.K. unemployment has reduced due to the expanded monetary policy, consistent with the prediction of the Phillip's curve.
\end{abstract}

Keywords: brexit announcement, international fisher effect, purchasing power parity, unemployment, inflation rate

\section{Introduction}

The purpose of this paper is to examine the protectionist motivations driving Brexit policy and to form an understanding of the short-term response, and consider the longer-term impact such policies will have for major economic indicators, including unemployment and inflation rates and, ultimately, the direction of the $€ / £$ exchange rate. Despite both EU and UK governments being far from agreement, and a timetable to achieve greater certainty of Brexit's impact not yet understood, we can, however, look at the proposed restriction of non-UK EU member migration and apply core economic concepts and empirical research to help explain and form a prediction regarding the future value of the British pound relative to the Euro.

We hypothesize that the protectionist nature of Brexit policy has contributed to lowering UK unemployment and prompted wage growth. Both effects are considered positive for UK citizens, however wage growth is positively related to inflation. Inflation, we argue, is strongly linked to the depreciating pound, which could facilitate both positive and negative consequences for the UK economy. To test this hypothesis, we have sourced and compared preand post-Brexit data to investigate the extent of support for our hypothesis. Our intention is not to agree, nor disagree with the Brexit decision. Rather, our intention is to raise greater understanding of the implications of the vote and importance of same. In doing so, the paper serves to prompt readers to consider how the UK is best positioned to address the implications. The study will not confirm specific outcomes, however we believe our predictions and supporting data will prove interesting to a wide audience, particularly as our predictions relate to the future of the UK's labor market, monetary policy options, foreign trade and international competitiveness.

"Brexit", a popular nickname and portmanteau, refers to Britain's vote to exit the European Union (EU) following a decades-long partnership with the economic and political union of 28 European nations. The EU formed an internal market governed by policies promoting the free movement of people, capital, goods and services. Whilst former UK Prime Minister David Cameron favored remaining in the EU, he sought to do so with renegotiated terms directed at protecting the UK's economic governance, competitiveness and sovereignty, whilst also restricting EU immigration. The latter resonated with the British public and proved a primary motivation for the slim-majority (51.9\%) (Note 1) who voted for the UK to leave the union. Of major concern was a perception that British citizens were worse off with EU membership due to the level of EU migrants gaining immediate access to in-work and out-of-work employment 
benefits paid for by the UK tax-payer, as well as the view that the additional labor supply adversely affected employment opportunities and wage growth (Note 2).

Despite being a close vote, with subsequent protests and a $4 \mathrm{~m}+$ signature petition to repeat the June 2016 referendum, the UK is still proceeding and Prime Minister, Teresa May, recently triggered Article 50 of the EU Lisbon Treaty to commence voluntary EU departure. Negotiating the terms of departure are still in an embryonic state with many decisions, and consequences of these decisions yet to be understood. Immediately following the Brexit vote the value of the pound fell $7 \%$ and $10 \%$ against the euro and dollar respectively (Note 3) and has remained significantly lower than the pre-vote period despite the lack of clarity regarding the severity, or not, of the future terms to which the UK will be subject. On a global scale, Brexit has attracted a lot of attention, both gaining support and raising significant concerns for UK and EU citizens, businesses and policy makers going forward. Many economists, central bankers, industry and foreign exchange experts have felt compelled to voice their view regarding the anticipated outcomes for the UK following the Brexit vote. Despite the mass of opinions, to the best of our knowledge there has not been any formal data study published to date which captures the impact Brexit's proposed protectionist policy will pose on the relationship connecting UK unemployment, inflation and, ultimately, the future relative value of the British Pound. Our study attempts to fill this void.

This paper is organized as follows. First, we discuss relevant empirical research and related literature to aid development of our hypothesis in our 'Literature Review' section. Following presentation of our hypothesis we discuss data sourcing, data measurement and data analysis methodologies in our 'Research' section. Next, our 'Results' section presents our findings from our research and we close with our 'Further Discussion' section which outlines potential limitations to this study as well as future extensions to this research as the effects of Brexit become more apparent, which could bolster scholarly research regarding the application of frameworks used and relating to consequences of key economic influencers such as protectionism and foreign exchange.

\section{Literature Review and Hypothesis Formulation}

\subsection{Literature Review}

The desire for a greater understanding of foreign exchange predictors has heightened as international trade continues to grow. An increasing number of firms need to plan future global demand for their products and adopt financial strategies to best protect the value of related foreign cash flows which are subject to exchange rate movement volatility. A commonly used measure to predict the foreign exchange value of a currency is the concept of Purchasing Power Parity (“PPP”).

Based on the 'law of one price', Cassel (1918) developed PPP which asserts that an identical good in different markets will be the same price once each price is converted to a common currency. Furthermore, as each market has a different inflation rate, the relative prices of goods in each market will change, which, in turn will change the exchange rate. The concept of PPP states that the market with the higher inflation rate, whereby prices are rising relatively faster, would see the value of its currency depreciate relative to the second market.

Following the 1970s collapse of Bretton Woods, an international monetary management system incorporating major industrialized nations, many previously fixed currencies, including the United States Dollar and Great British Pound, converted to become free-floating. Such a significant event prompted a wealth of research into the key determinants and predictors of changes to floating exchange rates, much of which tested the validity of PPP as a predictor of exchange rate movements (Taylor and Taylor, 2004). We note support for PPP as a predictor of exchange rate movements in some form (Dornbusch and Krugman, 1974) and Rogoff (1996) asserts "most [economists] instinctively believe in some variant of PPP as an anchor for long-run real exchange rates." For example, in "Is Purchasing Power Parity a Useful Guide to the Dollar?", Hakkio (1992) provides evidence to support the influence of inflation rate differentials between home and foreign nations to be a viable predictor of future exchange rates between nations.

One explanation for PPP's stronger holding in the longer-term is the existence of substantial barriers, such as transportation costs, which can facilitate exchange rate deviation from PPP in the short-term, and once overcome correct towards PPP in the longer term (Abuaf and Jorion, 1990), although the view is not fully agreed (Giddy and Dufey, 1975; Adler and Lehman, 1983). Of interest to our study, however, is Frenkel's review of "The Collapse of Purchasing Power Parity in the 1970s" where he cited previous research indicated little relationship between short-run inflation differentials between nations and the short-run changes in exchange rates. Frenkel (1979, 1981a, 1981b) reported that, whilst PPP did little to explain U.S. dollar versus European currency exchange rates in the short-run, PPP did perform much better as an explanatory of exchange rate behavior between sets of European currencies. Adding to 
Frenkel's research and motivated by a dearth of academic literature on parity relations' validity as a predictor of daily spot rates in the short-term, Jo et al. (2016), explored whether PPP and IFE were viable frameworks to predict the expected spot rate of Swiss franc against the Euro following the unpegging of the Swiss franc by the Swiss National Bank in January 2015. They concluded that whilst PPP and IFE were not perfect predictor models, they still proved very useful to gain an insight into the directional trend of spot rates in the short-term. As our study is also reviewing relationships between economic variables in Europe the observations of Frenkel (1981b) and Jo et al. (2016) are particularly relevant. One conclusion Frenkel formed is that closer geographic proximity allowed lower transportation costs and, when coupled with lower trade barriers, allowed more rapid correction of exchange rates in response to changes in the inflation rate differential.

Finally, a simple historic review of the Russian ruble, Japanese yen and South Korean won indicate rapid inflation and significant currency depreciation to be major and common consequences of currency crises. Whilst we are not suggesting the British pound to be in crises, we can apply the same logic regarding the impact of rising relative inflation rates to the UK/EU case. As such, we believe PPP should be a useful predictor of the future value of the pound for the purpose of this study. Thus, PPP predicts that to the extent that Brexit announcement is followed by U.K. expansionary monetary policy to boost the U.K. employment rate, the U.K. inflation rate will increase and the value of the British Pound will depreciate.

A second method for foreign exchange forecasting is the use of the International Fischer Effect ("IFE"), an equation related to the relative PPP concept albeit hypothesizing that the expected quantum and direction of spot exchange rate changes between two currencies will be equal and opposite to the nominal interest rate differential. IFE reflects the notion that higher nominal interest rates correlate with expectations of inflation, and thus states that a nation with a higher nominal interest rate will see its currency depreciate relative to another nation with a lower nominal interest rate. Frenkel's (1979), Meese and Rogoff's (1988), and Chen and Tsang's (2013) observations of interest rates in a variety of different countries supports IFE in their conclusion that the interest rate differential between two countries can determine the appreciation or depreciation of the home country's exchange rate. The UK and EU interest rate differential should, therefore, prove useful to predict the future value of the pound, and we would expect that the directional change of the expected $€ / £$ spot rate calculated using IFE will mirror and validate our PPP calculations relating to the same expected exchange rate.

While the above studies enhance our understanding of the relation among inflation rate, interest rate, and the expected future spot exchange rate, the prior studies do not directly guide us to understand the direct effect of the Brexit announcement on the British pound value and UK unemployment rate. As our key motivation for this study, however, is to understand how the Brexit vote will influence the value of the British pound, we are interested in literature to aid our understanding of how a nation's degree of protectionism, or openness, relative to other nations influences exchange rates. The goal of protectionist policy is to restrain international trade in order to 'protect' domestic businesses and jobs from foreign competition. Whilst the most common protectionist actions include tariffs and quotas on foreign imports, or granting subsidies to domestic firms, the UK's intention to restrict labor mobility of EU citizens, a key motivation of Brexit support, is considered an act to protect domestic jobs and workers from foreign competition, and is thus considered a protectionist stance. Linked to labor mobility restrictions, EU companies will face greater costs, akin to tariffs, and become less inclined to relocate and hire across UK borders.

Fouda (2012) evidenced how protectionist policies can not only negatively affect the economy of the home country, being the UK in this case, but also introduce negative consequences for their direct trading partners too. Such research is useful to understand the potential further consequences, including retaliation tactics from EU members, which may further impact the UK and the value of its currency.

\subsection{Hypothesis Formulation}

We postulate that the protectionist nature will be followed by the potential depreciation of the British Pound to the extent that the international parity conditions of PPP and IFE hold around the Brexit announcement. For instance, Romer (1993) suggests an indirect relationship between relative openness and exchange rates through identification of a negative link between the level of trade openness (i.e. level non- protectionist policy) and the level of inflation. Whilst economists subsequently challenged Romer's explanation of the openness and inflation relationship puzzle (Temple, 2002), they nevertheless agree a relationship exists. Gruben and Mcleod (2004), for example, revisited the openness-inflation debate and confirmed a higher degree of trade openness was also associated with less variable inflation and stronger dis-inflation effects with floating exchange rates. The UK's decision to exit the EU has, therefore, effectively reduced its openness and confirmed a higher degree of protectionist policy relative to the EU, which our 
literature review suggests will lead to heightened inflation in the UK economy and subsequent depreciation of the British pound.

We expect to see an increase in UK inflation levels, be it due to firms passing higher wage costs on to consumers, higher wages enhancing the level of discretionary spend and raising competition to buy a finite set of consumer goods, or another plausible rationale. Given our understanding of PPP theory, and the indirect link between PPP and the IFE, we expect this rise in inflation will correspond with a declining $€ / €$ exchange rate or, to be more specific, the depreciation of the British pound relative to the Euro and that the pound will continue to depreciate should UK inflation levels continue to out-strip EU inflation levels.

Hypothesis 1 (H1): Brexit announcement will be followed by the decrease of the U.K. pound value.

The Phillips Curve is a prominent economic concept developed by British Economist A. W. Phillips (1958) as he studied the explanatory factors of nominal wages. Using time-series economic data, Phillips plotted and observed an inverse relationship between the inflation and unemployment rates within the UK economy. High unemployment was associated with low inflation, and vice versa. Phillips' study was repeated, and results confirmed across multiple nations, including the United States (Samuelson and Solow, 1960), and over time gained sufficient credibility to be a key influence on government policies. Our literature review suggests Brexit's core objective of restricting non-UK EU citizen migration into the UK will reduce unemployment levels and increase inflation, and thus supports the Philips Curve theory. Since the 1970s many scholars and economists have questioned the validity of the Phillips Curve, with some concluding weak evidence in support and others claiming the curve to have shifted and/or flattened. Nevertheless, there remains significant support that the Phillips Curve does still hold, especially in the short-run. Nobile and Skarica (2016), for example, conducted a large study and demonstrated a negative relationship between inflation and economic slack (unemployed resources) for countries across the Eurozone. As PPP argues inflation to be a good predictor of future spot prices, we are keen to uncover evidence that the Phillips Curve inverse relationship between unemployment and inflation continues to hold for the UK, both before and after the Brexit vote, to allow us greater confidence in the robustness of our prediction for the longer term directional change of the $€ / £$ spot rate using the PPP and IFE methodologies and, therefore, the connection between unemployment, inflation and the $€ / £$ spot rate. To the extent that Phillips curve holds after the Brexit announcement, at least in the short term, we expect to observe;

Hypothesis 2 (H2): Brexit announcement will be followed by a negative relation between inflation rate and unemployment rate.

Motivated by rising concerns that immigrants were taking away from natives and causing wages to reduce in major European economies, Brücker, Jahn and Upward (2012), studied the effects on UK wage inflation and unemployment levels upon opening its borders to non-UK EU labor mobility in the early 1990s. Using data from 1993 to 2006, their research estimated the wage and employment effects of the increased migration into the UK. They demonstrated that the wage elasticity in the UK was high, and that the effect of a one percent immigration reduces UK wages by $0.29 \%$ and increases the unemployment rate by 0.11 percentage points. This research is useful to guide our understanding of the impact that the UK's openness to net migration, or lack of, will have on UK labor markets. The study suggests by reversing openness of its labor markets, the UK will experience wage inflation and lower unemployment.

We assert the announcement of the "yes' vote to be a signal of the UK's strengthened protectionist policy. Non-UK EU citizens will be less inclined to contemplate employment in the UK, as the core Brexit goal of restricting inward migration has swiftly depleted the probability of success. As such, we expect the Brexit announcement will have prompted an immediate decline in net migration into the UK from EU member states. As a consequence of fewer migrants entering the UK, we expect a reduction in the level of labor supply for a given set of UK employment opportunities (labor demand). UK unemployment levels will fall in the short-term. Furthermore, with reduced employment 'slack', whereby labor demand outweighs labor supply, we expect wage inflation to accelerate as businesses are incentivized to increase wages to attract talent from a more limited talent pool, and UK employment level will increase. Consequently, we postulate that;

Hypothesis 3 (H3): Brexit announcement will be followed by U.K. unemployment rate decrease.

\section{Data and Methodology}

As noted in the Literature Review, PPP is considered a robust predictor of exchange rates movements. The first stage of our analysis, therefore, requires the computation of the forecast $€ / £$ spot rate using the PPP technique. We also intend to compute an IFE prediction, as we would expect both techniques to show the same effect on a given set of currencies despite different inputs into each equation. 
PPP: Using data from The Bank of England, we obtained a sample of the daily $€ / £$ spot prices for the period $1^{\text {st }}$ September 2015 to $28^{\text {th }}$ April 2017, being approximately ten months prior, and ten months after the Brexit referendum. This data period was chosen to allow us to not only analyze the specific effects of the Brexit "yes" vote on the $€ / £$ exchange rates, but to also ensure we used a long enough period to be comfortable we could identify and account for any seasonal effects on the exchange rates that may exist.

As previously explained, the concept of PPP asserts that the exchange rate between two currencies, the British Pound and Euro for the purpose of this study, is in equilibrium when the purchasing power is the same in each area. This definition implies that, if prices are rising in the UK relative to the EU, for example, the currency of the UK (British pound) must depreciate to maintain purchasing power parity. In other words, the inflation rate differential between the two nations will influence exchange rates in order to maintain purchasing power parity. In our assessment, the inflation rate differential is denoted as $\left(I_{h}-I_{f}\right)$, whereby $I_{h}$ refers to the home nation inflation rate (UK) and $I_{f}$ the foreign country inflation rate (EU). Inflation data for the UK and EU were obtained from the UK's Office of National Statistics and Eurostat, the statistical service of the European Commission, respectively. Unlike the daily spot-rate, inflation rates are calculated and reported on a monthly basis only.

The PPP formula (1) shows that to be in parity, the inflation differential between two nations must equal the forward (F)-to-spot rate (S) exchange rate differential for $€ / €$ rates. For the purpose of our study, we do not know the forward rate as this is what we are trying to assess. As such, we substitute $\mathrm{F}$ with $\mathrm{E}(\mathrm{S})$, being the expected spot rate.

$$
\frac{\underline{I}_{h}-I_{f}}{1+I_{f}}=\frac{F-S}{S}=\frac{E(S)-S}{S}
$$

By re-arranging this formula, we isolate our variable of interest $\mathrm{E}(\mathrm{S})$ to show how we will use our daily spot rate, home (UK) and foreign (EU) inflation rates within this re-arrangement to forecast the future spot rate:

$$
\mathrm{E}(\mathrm{S})=\mathrm{S} \times\left\{\left(\mathrm{I}_{\mathrm{h}}-\mathrm{I}_{\mathrm{f}}\right) /\left(1+\mathrm{I}_{\mathrm{f}}\right)\right\}+\mathrm{S}
$$

After calculating the $\mathrm{E}(\mathrm{S})$ each day using the relevant data for that specific day within the data set period we will assess the overall trend, if any, of $E(S)$ for the $€ / £$. A negatively sloped line graph over time, for example, is indicative of forecast depreciation in the value of the British pound.

IFE: We next turn our attention to the International Fisher Effect as we aim to confirm the results of the PPP forecasting method using this alternative methodology. Similarly to PPP, the concept of IFE uses the nominal interest rate differential, as opposed to the inflation rate differential, to predict $\mathrm{E}(\mathrm{S})$ between two currencies. In equilibrium, the forward/spot rate differential equals the interest rate differential between the home nation $\left(\mathrm{i}_{\mathrm{h}}\right)$ and the foreign nation $\left(\mathrm{i}_{\mathrm{f}}\right)$ :

$$
\frac{\mathrm{i}_{\underline{h}}-\underline{i}_{\underline{f}}}{1+\mathrm{i}_{\mathrm{f}}}=\frac{\mathrm{F}-\mathrm{S}}{\mathrm{S}}=\frac{\mathrm{E}(\mathrm{S})-\mathrm{S}}{\mathrm{S}}
$$

As with our PPP assessment, $\mathrm{i}_{\mathrm{h}}$ refers to UK interest rates and $\mathrm{i}_{\mathrm{f}}$ the EU interest rate. Re-arranging this formula, we isolate our predicted future spot price, $\mathrm{E}(\mathrm{S})$, calculation to be:

$$
\mathrm{E}(\mathrm{S})=\mathrm{S} \times\left\{\left(\mathrm{i}_{\mathrm{h}}-\mathrm{i}_{\mathrm{f}}\right) /\left(1+\mathrm{i}_{\mathrm{f}}\right)\right\}+\mathrm{S}
$$

We obtained overnight LIBOR rates for the British Pound and Euro, our home and foreign interest rate variables respectively, from the Federal Reserve Economic Data (FRED) database. Once again, we calculated E(S) using the IFE technique for each day during the data-set period (September 2015 - April 2017). Not only do we expect to see the $E(S)$ of $€ / £$ decline over time, we expect the results obtained under IFE will reflect the same directional change in $E(S)$ obtained under our PPP results.

\section{Results}

In Figure 1, we plot the estimated future spot price for each daily spot rate over the research period calculated using both the PPP and IFE estimation frameworks. Both Table 1 and Figure 1 indicate that both PPP and IFE estimates remain very closely aligned over time.

Whilst IFE estimates were typically higher than PPP, albeit by a minor margin, prior to the EU referendum, it is interesting to note the elimination of this margin and the two estimation technique results flowing in tandem soon after the UK decided to leave the EU. The results obtained under IFE, therefore, do appear to validate our use of PPP as a tool to predict future spot-rates. The approximate date of the Brexit vote is identified by the red-dashed line in all charts. A significant drop in the pound value is clearly evident immediately following the Brexit vote, and despite some recovery the pound value has continued to fluctuate around a much lower value in the post-Brexit period to date. 
Furthermore, our comparison of the actual daily spot rates and PPP spot rate estimates over time (Figure 2) show that they also follow the same directional trend and are closely aligned both pre-and-post the Brexit vote, thus adding support to PPP and IFE as being effective methods to estimate spot rate value trends.

Table 1. Actual spot rate and predicted rates based on IFE and PPP

\begin{tabular}{|c|c|c|c|c|c|c|c|}
\hline Date & $\begin{array}{l}\text { Actual Spot } \\
\text { Rate } \\
\text { (EUR / GBP) }\end{array}$ & $\begin{array}{l}\text { UK Inflation } \\
\text { Rate }\end{array}$ & $\begin{array}{c}\text { EU Inflation } \\
\text { Rate }\end{array}$ & $\begin{array}{c}\text { Spot Rate Based } \\
\text { on PPP (EUR / } \\
\text { GBP) }\end{array}$ & UK UBOR & EU LIBOR & $\begin{array}{c}\text { Spot Rate } \\
\text { Based on IFE } \\
\text { (EUR / GBP) }\end{array}$ \\
\hline 01-Sep-15 & 1.3615 & $-0.105 \%$ & $-0.09 \%$ & 1.3614 & $0.48 \%$ & $-0.18 \%$ & 1.3705 \\
\hline 08-sep-15 & 1.3738 & $-0.10 \%$ & $-0.09 \%$ & 1.3737 & $0.48 \%$ & $-0.18 \%$ & 1.3829 \\
\hline 15 -sep-15 & 1.3623 & $-0.10 \%$ & $-0.09 \%$ & 1.3622 & $0.48 \%$ & $-0.18 \%$ & 1.3713 \\
\hline $22-$ sep-15 & 1.3781 & $-0.10 \%$ & $-0.09 \%$ & 1.3780 & $0.48 \%$ & $-0.18 \%$ & 1.3872 \\
\hline 29-Sep-15 & 1.3494 & $-0.10 \%$ & $-0.09 \%$ & 1.3493 & $0.48 \%$ & $-0.18 \%$ & 1.3583 \\
\hline $06-$-oct-15 & 1.3507 & $-0.10 \%$ & $0.12 \%$ & 1.3477 & $0.48 \%$ & $-0.18 \%$ & 1.3596 \\
\hline 13-Oct-15 & 1.3386 & $-0.10 \%$ & $0.12 \%$ & 1.3357 & $0.48 \%$ & $-0.18 \%$ & 1.3475 \\
\hline 20-Oct-15 & 1.3631 & $-0.10 \%$ & $0.12 \%$ & 1.3601 & $0.48 \%$ & $-0.18 \%$ & 1.3722 \\
\hline 27-Oct-15 & 1.3855 & -0.1056 & $0.12 \%$ & 1.3825 & $0.48 \%$ & $-0.18 \%$ & 1.3947 \\
\hline 03-Nov-15 & 1.4062 & $0.10 \%$ & $0.15 \%$ & 1.4055 & $0.48 \%$ & $-0.18 \%$ & 1.4155 \\
\hline 10-Nov-15 & 1.4131 & $0.10 \%$ & $0.15 \%$ & 1.4124 & $0.48 \%$ & $-0.18 \%$ & 1.4225 \\
\hline 17-Nov-15 & 1.4286 & $0.10 \%$ & $0.15 \%$ & 1.4279 & $0.48 \%$ & $-0.18 \%$ & 1.4381 \\
\hline 24-Nov-15 & 1.4161 & $0.10 \%$ & $0.15 \%$ & 1.4154 & $0.48 \%$ & $-0.18 \%$ & 1.4255 \\
\hline 01-Dec-15 & 1.4191 & $0.20 \%$ & $0.23 \%$ & 1.4187 & $0.48 \%$ & $-0.19 \%$ & 1.4286 \\
\hline o8-Dec-15 & 1.3783 & $0.20 \%$ & $0.23 \%$ & 1.3779 & $0.48 \%$ & $-0.19 \%$ & 1.3876 \\
\hline 15-Dec-15 & 1.3779 & $0.20 \%$ & $0.23 \%$ & 1.3775 & $0.48 \%$ & $-0.28 \%$ & 1.3884 \\
\hline 22-Dec-15 & 1.3518 & $0.20 \%$ & $0.23 \%$ & 1.3514 & $0.48 \%$ & $-0.28 \%$ & 1.3621 \\
\hline 29-Dec-15 & 1.3567 & $0.20 \%$ & $0.23 \%$ & 1.3563 & $0.48 \%$ & $-0.28 \%$ & 1.3671 \\
\hline 05-Jan-16 & 1.3661 & $0.30 \%$ & $0.33 \%$ & 1.3657 & $0.48 \%$ & $-0.28 \%$ & 1.3765 \\
\hline $12-\operatorname{Jan}-16$ & 1.3275 & $0.30 \%$ & $0.33 \%$ & 1.3271 & $0.48 \%$ & $-0.28 \%$ & 1.3376 \\
\hline 19-Jan-16 & 1.298 & $0.30 \%$ & $0.33 \%$ & 1.2976 & $0.48 \%$ & $-0.28 \%$ & 1.3080 \\
\hline $26-\operatorname{Jan}-16$ & 1.3204 & $0.30 \%$ & $0.33 \%$ & 1.3200 & $0.48 \%$ & $-0.28 \%$ & 1.3305 \\
\hline $02-$ Feb-16 & 1.3185 & $0.30 \%$ & $-0.15 \%$ & 1.3244 & $0.48 \%$ & $-0.28 \%$ & 1.3286 \\
\hline $09-$ Feb-16 & 1.2806 & $0.30 \%$ & $-0.15 \%$ & 1.2864 & $0.48 \%$ & $-0.28 \%$ & 1.2904 \\
\hline $16-$ feb-16 & 1.2839 & $0.30 \%$ & $-0.15 \%$ & 1.2897 & $0.48 \%$ & $-0.28 \%$ & 1.2937 \\
\hline $23-F e b-16$ & 1.2795 & $0.30 \%$ & $-0.15 \%$ & 1.2853 & $0.48 \%$ & $-0.28 \%$ & 1.2893 \\
\hline 01-Mar-16 & 1.2822 & $0.50 \%$ & $-0.04 \%$ & 1.2891 & $0.48 \%$ & $-0.28 \%$ & 1.2920 \\
\hline 08-Mar-16 & 1.2851 & $0.50 \%$ & $-0.04 \%$ & 1.2920 & $0.48 \%$ & $-0.29 \%$ & 1.2950 \\
\hline 15-Mar-16 & 1.2747 & $0.50 \%$ & $-0.04 \%$ & 1.2816 & $0.48 \%$ & $-0.29 \%$ & 1.2846 \\
\hline 22-Mar-16 & 1.2663 & $0.50 \%$ & $-0.04 \%$ & 1.2731 & $0.48 \%$ & $-0.39 \%$ & 1.2773 \\
\hline 30-Mar-16 & 1.2725 & $0.50 \%$ & $-0.04 \%$ & 1.2794 & $0.48 \%$ & $-0.39 \%$ & 1.2836 \\
\hline $06-A p r-16$ & 1.2384 & $0.30 \%$ & $-0.24 \%$ & 1.2451 & $0.48 \%$ & $-0.39 \%$ & 1.2493 \\
\hline $13-A p r-16$ & 1.259 & $0.30 \%$ & $-0.24 \%$ & 1.2658 & $0.48 \%$ & $-0.39 \%$ & 1.2700 \\
\hline $20-A p r-16$ & 1.2711 & $0.30 \%$ & $-0.24 \%$ & 1.2780 & $0.48 \%$ & $-0.39 \%$ & 1.2823 \\
\hline $27-A p r-16$ & 1.2856 & $0.30 \%$ & $-0.24 \%$ & 1.2926 & $0.48 \%$ & $-0.39 \%$ & 1.2969 \\
\hline $04-M a y-16$ & 1.2601 & $0.30 \%$ & $-0.10 \%$ & 1.2651 & $0.48 \%$ & $-0.40 \%$ & 1.2712 \\
\hline 11-May-16 & 1.2653 & $0.30 \%$ & $-0.10 \%$ & 1.2704 & $0.48 \%$ & $-0.40 \%$ & 1.2765 \\
\hline 18-Мay-16 & 1.2961 & $0.30 \%$ & $-0.10 \%$ & 1.3013 & $0.48 \%$ & $-0.40 \%$ & 1.3076 \\
\hline 25-May-16 & 1.3202 & $0.30 \%$ & $-0.10 \%$ & 1.3255 & $0.48 \%$ & $-0.40 \%$ & 1.3319 \\
\hline 01-Jun-16 & 1.2898 & $0.50 \%$ & $0.08 \%$ & 1.2952 & $0.48 \%$ & $-0.40 \%$ & 1.3012 \\
\hline 08-Jun-16 & 1.2773 & $0.50 \%$ & $0.08 \%$ & 1.2827 & $0.48 \%$ & $-0.40 \%$ & 1.2885 \\
\hline 15-Jun-16 & 1.2634 & $0.50 \%$ & $0.08 \%$ & 1.2687 & $0.48 \%$ & $-0.39 \%$ & 1.2745 \\
\hline 22-Jun-16 & 1.3018 & $0.50 \%$ & $0.08 \%$ & 1.3073 & $0.48 \%$ & $-0.40 \%$ & 1.3133 \\
\hline 29-Jun-16 & 1.2177 & $0.50 \%$ & $0.08 \%$ & 1.2228 & $0.48 \%$ & $-0.40 \%$ & 1.2284 \\
\hline
\end{tabular}


Table 1 Cont'd. Actual spot rate and predicted rates based on IFE and PPP

\begin{tabular}{|c|c|c|c|c|c|c|c|}
\hline Date & $\begin{array}{c}\text { Actual Spot } \\
\text { Rate } \\
\text { (EUR / GBP) }\end{array}$ & $\begin{array}{l}\text { UK Inflation } \\
\text { Rate }\end{array}$ & $\begin{array}{c}\text { EU Inflation } \\
\text { Rate }\end{array}$ & $\begin{array}{c}\text { Spot Rate } \\
\text { Based on PPP } \\
\text { (EUR / GBP) }\end{array}$ & UK UBOR & EU LIBOR & $\begin{array}{c}\text { Spot Rate } \\
\text { Based on IFE } \\
\text { (EUR / GBP) }\end{array}$ \\
\hline 06-Jul-16 & 1.1639 & $0.60 \%$ & $0.16 \%$ & 1.1690 & $0.48 \%$ & $-0.40 \%$ & 1.1742 \\
\hline 13-Jul-16 & 1.1903 & $0.60 \%$ & $0.16 \%$ & 1.1955 & $0.48 \%$ & $-0.40 \%$ & 1.2008 \\
\hline 20-Jul-16 & 1.1969 & $0.60 \%$ & $0.16 \%$ & 1.2022 & $0.48 \%$ & $-0.40 \%$ & 1.2075 \\
\hline 27-Jul-16 & 1.1936 & $0.60 \%$ & $0.16 \%$ & 1.1988 & $0.48 \%$ & $-0.40 \%$ & 1.2041 \\
\hline 03 -Aug-16 & 1.1924 & $0.60 \%$ & $0.24 \%$ & 1.1967 & $0.48 \%$ & $-0.40 \%$ & 1.2029 \\
\hline $10-A u g-16$ & 1.1656 & $0.60 \%$ & $0.24 \%$ & 1.1698 & $0.23 \%$ & $-0.40 \%$ & 1.1730 \\
\hline $17-A u g-16$ & 1.1538 & $0.60 \%$ & $0.24 \%$ & 1.1579 & $0.23 \%$ & $-0.40 \%$ & 1.1611 \\
\hline 24-Aug-16 & 1.1779 & $0.60 \%$ & $0.24 \%$ & 1.1821 & $0.23 \%$ & $-0.40 \%$ & 1.1854 \\
\hline $01-$ sep-16 & 1.1883 & $1.00 \%$ & $0.41 \%$ & 1.1953 & $0.23 \%$ & $-0.40 \%$ & 1.1958 \\
\hline 08-sep-16 & 1.181 & $1.00 \%$ & $0.41 \%$ & 1.1879 & $0.23 \%$ & $-0.40 \%$ & 1.1884 \\
\hline 15 -sep-16 & 1.1735 & $1.00 \%$ & $0.41 \%$ & 1.1804 & $0.23 \%$ & $-0.40 \%$ & 1.1809 \\
\hline $22-$ sep-16 & 1.1649 & $1.00 \%$ & $0.41 \%$ & 1.1717 & $0.23 \%$ & $-0.40 \%$ & 1.1723 \\
\hline 29-sep-16 & 1.156 & $1.00 \%$ & $0.41 \%$ & 1.1628 & $0.23 \%$ & $-0.40 \%$ & 1.1633 \\
\hline $06-$ Oct-16 & 1.1321 & $0.90 \%$ & $0.51 \%$ & 1.1365 & $0.23 \%$ & $-0.40 \%$ & 1.1393 \\
\hline 13-Oct-16 & 1.1054 & $0.90 \%$ & $0.51 \%$ & 1.1097 & $0.23 \%$ & $-0.41 \%$ & 1.1125 \\
\hline $20-$ Oct-16 & 1.1206 & $0.90 \%$ & $0.51 \%$ & 1.1249 & $0.23 \%$ & $-0.41 \%$ & 1.1277 \\
\hline 27-Oct-16 & 1.1155 & $0.90 \%$ & $0.51 \%$ & 1.1198 & $0.23 \%$ & $-0.41 \%$ & 1.1226 \\
\hline 01-Nov-16 & 1.1066 & $1.20 \%$ & $0.57 \%$ & 1.1135 & $0.23 \%$ & $-0.41 \%$ & 1.1137 \\
\hline $07-$ Nov-16 & 1.1232 & $1.20 \%$ & $0.57 \%$ & 1.1302 & $0.23 \%$ & $-0.40 \%$ & 1.1303 \\
\hline 14-Nov-16 & 1.1613 & $1.20 \%$ & $0.57 \%$ & 1.1686 & $0.23 \%$ & $-0.41 \%$ & 1.1687 \\
\hline 21-Nov-16 & 1.1744 & $1.20 \%$ & $0.57 \%$ & 1.1818 & $0.23 \%$ & $-0.41 \%$ & 1.1819 \\
\hline 28-Nov-16 & 1.1728 & $1.20 \%$ & $0.57 \%$ & 1.1801 & $0.23 \%$ & $-0.41 \%$ & 1.1803 \\
\hline 05-Dec-16 & 1.1848 & $1.60 \%$ & $1.14 \%$ & 1.1902 & $0.23 \%$ & $-0.41 \%$ & 1.1924 \\
\hline 12-Dec-16 & 1.1942 & $1.60 \%$ & $1.14 \%$ & 1.1996 & $0.23 \%$ & $-0.41 \%$ & 1.2018 \\
\hline 19-Dec-16 & 1.1874 & $1.60 \%$ & $1.14 \%$ & 1.1928 & $0.23 \%$ & $-0.41 \%$ & 1.1950 \\
\hline 28-Dec-16 & 1.1764 & $1.60 \%$ & $1.14 \%$ & 1.1818 & $0.23 \%$ & $-0.41 \%$ & 1.1839 \\
\hline 05 -Jan- 17 & 1.1719 & $1.80 \%$ & $1.76 \%$ & 1.1724 & $0.23 \%$ & $-0.41 \%$ & 1.1794 \\
\hline 12-Jan-17 & 1.147 & $1.80 \%$ & $1.76 \%$ & 1.1475 & $0.23 \%$ & $-0.41 \%$ & 1.1543 \\
\hline 19-Jan-17 & 1.1597 & $1.80 \%$ & $1.76 \%$ & 1.1602 & $0.23 \%$ & $-0.41 \%$ & 1.1671 \\
\hline $26-\operatorname{Jan}-17$ & 1.1797 & $1.80 \%$ & $1.76 \%$ & 1.1802 & $0.23 \%$ & $-0.41 \%$ & 1.1873 \\
\hline $01-$ Feb-17 & 1.1756 & $2.30 \%$ & $1.98 \%$ & 1.1793 & $0.23 \%$ & $-0.41 \%$ & 1.1831 \\
\hline $08-F e b-17$ & 1.1705 & $2.30 \%$ & $1.98 \%$ & 1.1742 & $0.22 \%$ & $-0.42 \%$ & 1.1780 \\
\hline $15-F e b-17$ & 1.1772 & $2.30 \%$ & $1.98 \%$ & 1.1809 & $0.22 \%$ & $-0.42 \%$ & 1.1848 \\
\hline $22-F e b-17$ & 1.1811 & $2.30 \%$ & $1.98 \%$ & 1.1848 & $0.22 \%$ & $-0.42 \%$ & 1.1887 \\
\hline 01-Mar-17 & 1.1669 & $2.30 \%$ & $1.54 \%$ & 1.1756 & $0.22 \%$ & $-0.42 \%$ & 1.1745 \\
\hline 07-Mar-17 & 1.1526 & $2.30 \%$ & $1.54 \%$ & 1.1612 & $0.22 \%$ & $-0.42 \%$ & 1.1601 \\
\hline 13-Mar-17 & 1.1466 & $2.30 \%$ & $1.54 \%$ & 1.1552 & $0.23 \%$ & $-0.42 \%$ & 1.1541 \\
\hline 20-Mar-17 & 1.15 & $2.30 \%$ & $1.54 \%$ & 1.1586 & $0.23 \%$ & $-0.43 \%$ & 1.1575 \\
\hline 27-Mar-17 & 1.1548 & $2.30 \%$ & $1.54 \%$ & 1.1634 & $0.23 \%$ & $-0.43 \%$ & 1.1623 \\
\hline 31-Mar-17 & 1.1694 & $2.30 \%$ & $1.54 \%$ & 1.1782 & $0.22 \%$ & $-0.42 \%$ & 1.1770 \\
\hline 07-Apr-17 & 1.167 & $2.70 \%$ & $1.87 \%$ & 1.1765 & $0.23 \%$ & $-0.42 \%$ & 1.1746 \\
\hline 19-Apr-17 & 1.1957 & $2.70 \%$ & $1.87 \%$ & 1.2054 & $0.22 \%$ & $-0.42 \%$ & 1.2035 \\
\hline $26-A p r-17$ & 1.1822 & $2.70 \%$ & $1.87 \%$ & 1.1918 & $0.22 \%$ & $-0.42 \%$ & 1.1899 \\
\hline
\end{tabular}




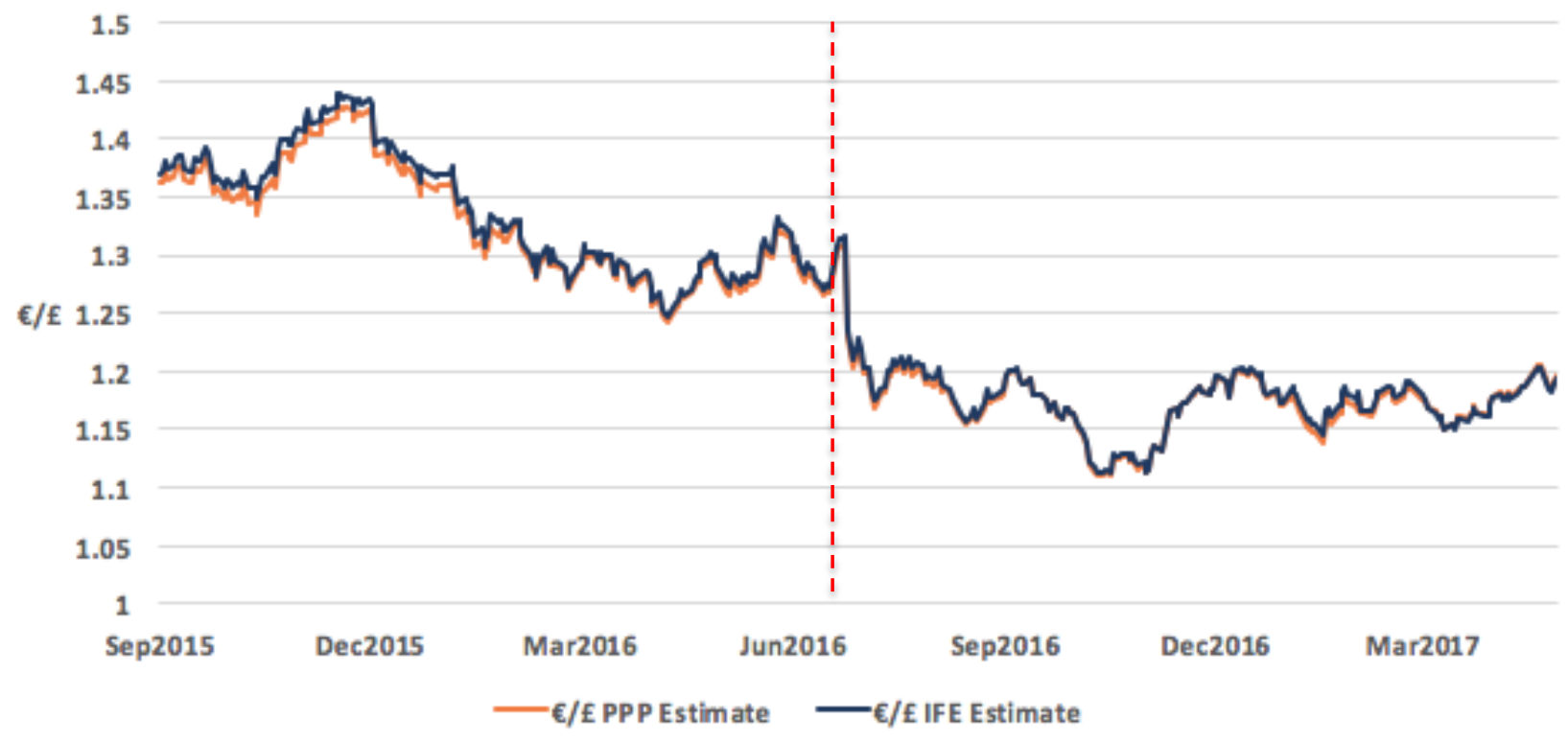

Figure 1. PPP and IFE estimations of future spot rates

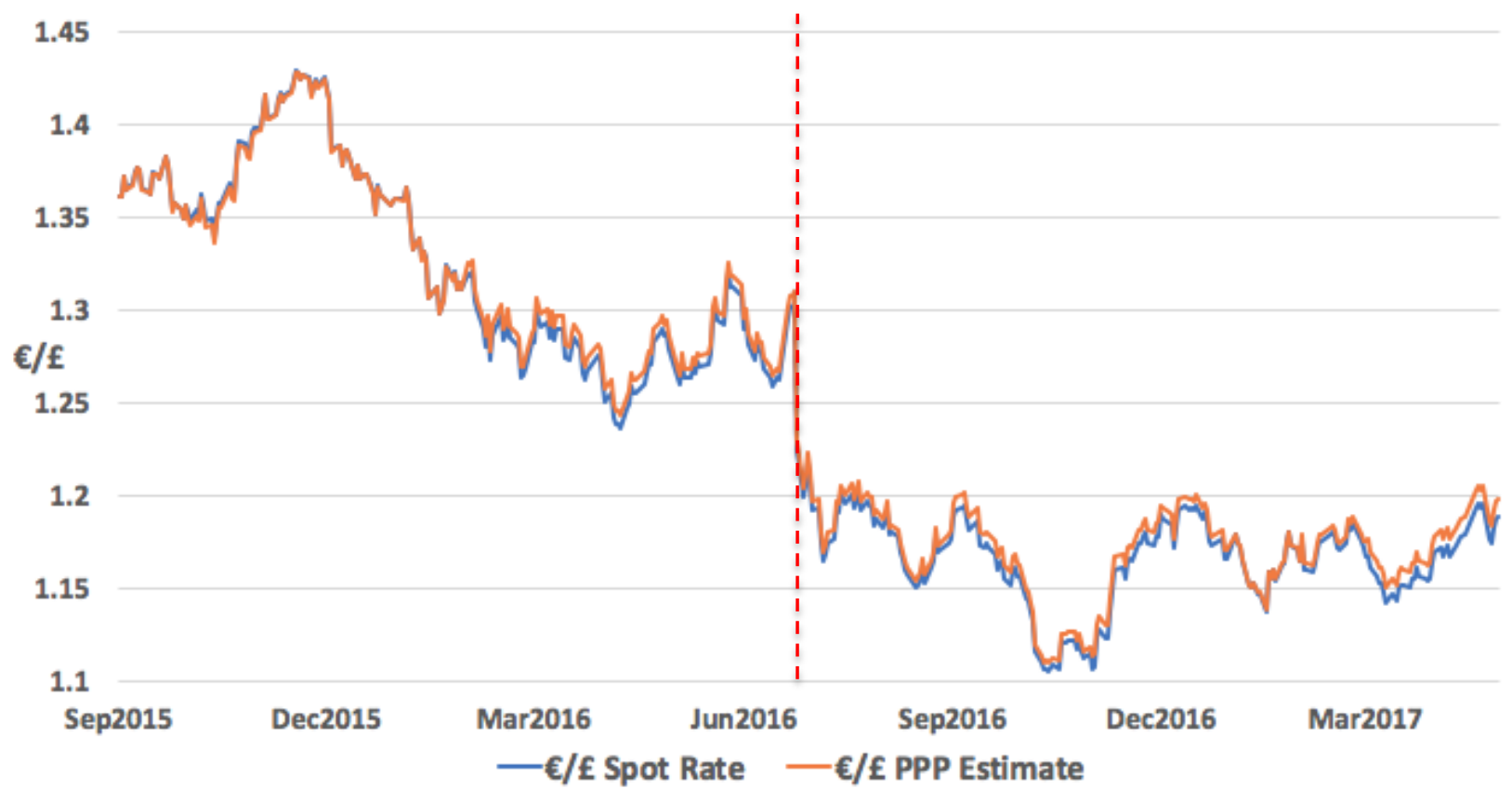

Figure 2. PPP estimates of future spot rates versus actual spot rates

And whilst the PPP and IFE tools will not confirm actual future spot rates, the charts support the notion of inflation and, more specifically, the inflation rate differential between nations as a key determinant of the directional change in future exchange rates involving each nation's currencies. Close review of Figure 2, one can see some evidence of the actual spot rate as a lag indicator. In other words, there is evidence that the actual $€ / £$ spot rate responds after the economy has started to follow a certain pattern or trend, or in this case, there is evidence the spot rate responds to a change in the inflation rate differential between the UK and EU. Such a statement is more apparent in Figure 3 which shows how the $€ / £$ spot rate has trended from Sept 2015 to April 2017 alongside the size of the inflation rate differential over the same period. 
Whilst not perfect correlation, one can see examples of periods where the inflation rate differential between UK and $\mathrm{EU}$ is rising, i.e. UK prices rising more rapidly than in the EU, followed by a period of a depreciating pound (Quarter 1, 2016). Similarly, we can note examples of a depleting inflation rate differential being followed by a period of pound appreciation. To summarize, a quick review of Figure 3 demonstrates an overall trend of a depreciating pound, being a declining $€ / £$ spot rate represented by a negative slope, accompanied by a trend of a rising inflation rate differential represented by a positive slope over time, and thus supporting our hypothesis $\mathrm{H} 1$.

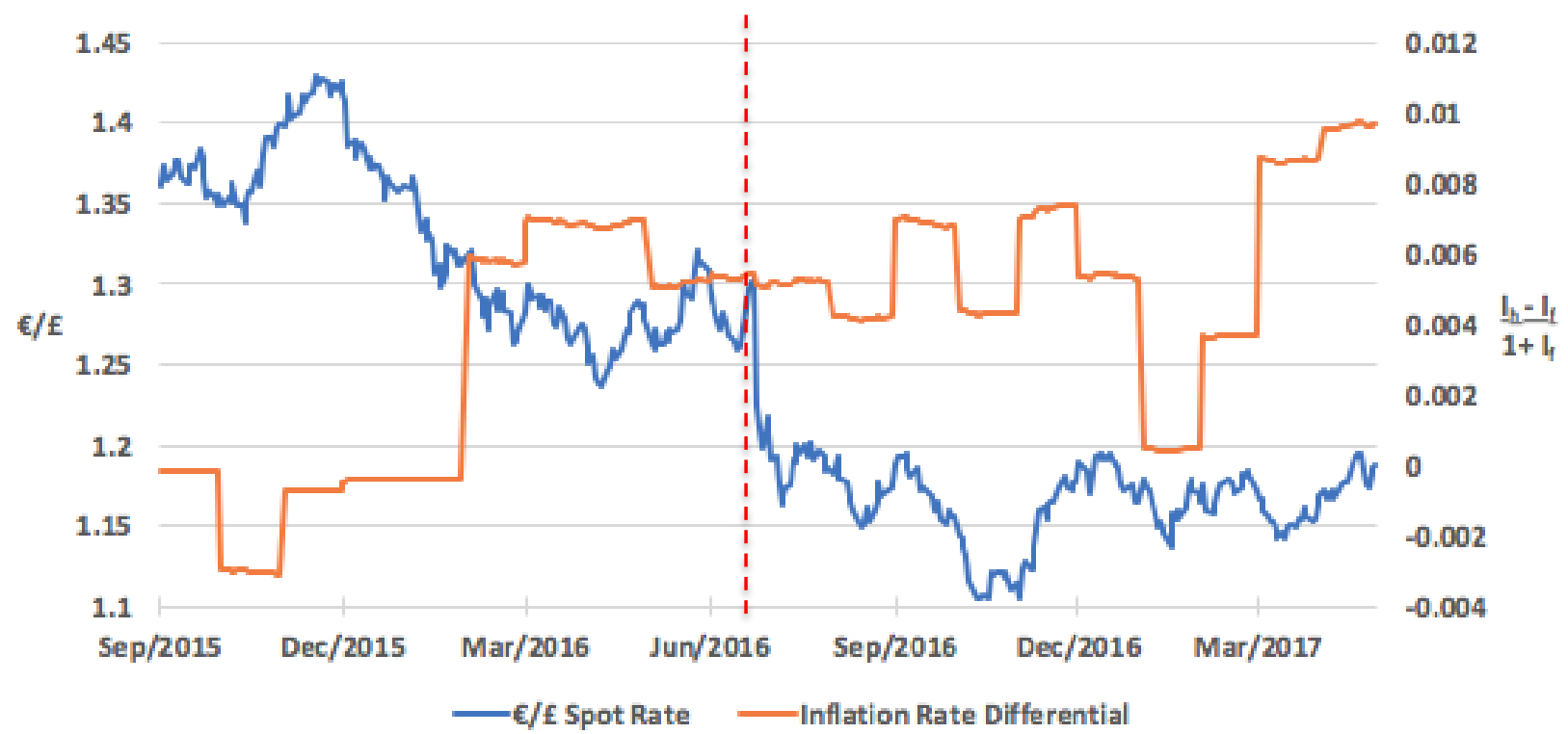

Figure 3. $€ / £$ Spot rate trend and UK inflation rate trend

Now that we have gathered evidence to support the notion of the UK-EU inflation rate differential as a key influencing factor of future $€ / £$ spot rates, we focus on our attention on the link between the UK's decision to restrict migration, and its consequences for UK inflation rates and the value of the British pound. The first stage of this process involves analysis of a relationship, if any, between UK unemployment rates and the UK inflation rate. We hope to demonstrate an inverse relationship supportive of the Phillips Curve.

Using data from the UK Office for National Statistics (ONS) we have extracted and paired monthly unemployment rate data with our monthly inflation rate data for an eighteen-month period, September 2015 to February 2017. At the time of writing this paper, February 2017 is the latest period whereby both inflation and unemployment data is available from the ONS. The ONS is a highly credible source, being "the UK's largest independent producer of official statistics and the recognized national statistical institute of the UK" (ONS website, May 2017). The ONS is also a key information source for policymakers, researchers and media reporters.

Using the ONS data, Table 2 shows the negative association between the UK inflation rate and unemployment rate. 
Table 2. UK Unemployment and inflation rates (Sept 2015 - Feb 2017)

\begin{tabular}{ccc}
\hline Date & $\begin{array}{c}\text { Unemployment } \\
\text { Rate }\end{array}$ & $\begin{array}{c}\text { Infaltion } \\
\text { Rate }\end{array}$ \\
\hline Sep-15 & $5.2 \%$ & $-0.1 \%$ \\
Oct-15 & $5.1 \%$ & $-0.1 \%$ \\
Nov-15 & $5.1 \%$ & $0.1 \%$ \\
Dec-15 & $5.1 \%$ & $0.2 \%$ \\
Jan-16 & $5.1 \%$ & $0.3 \%$ \\
Feb-16 & $5.1 \%$ & $0.3 \%$ \\
Mar-16 & $5.0 \%$ & $0.5 \%$ \\
Apr-16 & $4.9 \%$ & $0.3 \%$ \\
May-16 & $4.9 \%$ & $0.3 \%$ \\
Jun-16 & $4.9 \%$ & $0.5 \%$ \\
Jul-16 & $5.0 \%$ & $0.6 \%$ \\
Aug-16 & $4.8 \%$ & $0.6 \%$ \\
Sep-16 & $4.8 \%$ & $1.0 \%$ \\
Oct-16 & $4.8 \%$ & $0.9 \%$ \\
Nov-16 & $4.8 \%$ & $1.2 \%$ \\
Dec-16 & $4.7 \%$ & $1.6 \%$ \\
Jan-17 & $4.7 \%$ & $1.8 \%$ \\
Feb-17 & $4.6 \%$ & $2.3 \%$
\end{tabular}

In Figure 4, we have plotted actual unemployment/inflation combinations for each month in the review period and can clearly see an inverse relationship existing between the data points. We calculated the R-squared goodness of fit measure to be 0.8117 based on bivariate regressions which we believe reflects the data to be strongly supportive of the Phillips Curve concept, and that unemployment and inflation have a relatively stable inverse relationship, supporting $\mathrm{H} 2$.

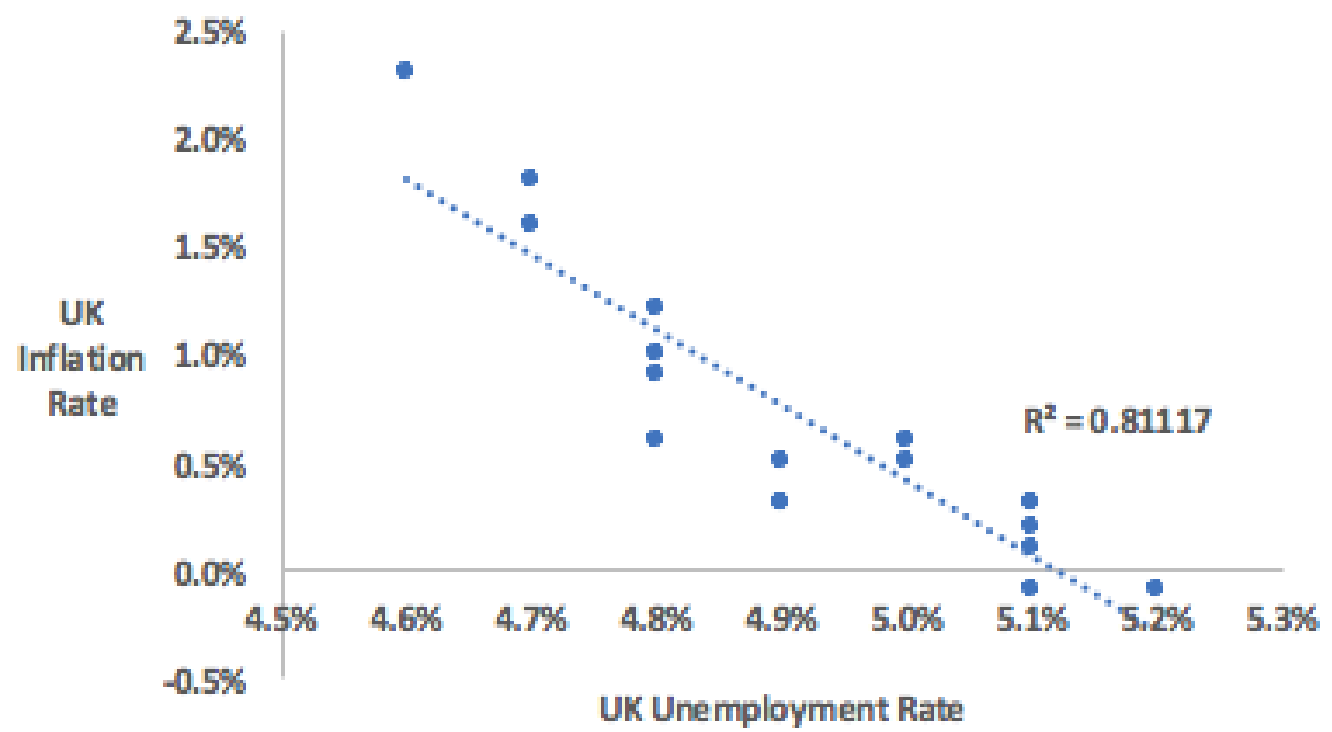

Figure 4. A plot of UK unemployment and inflation rate 
As the Philips Curve does not distinguish how unemployment and inflation trend over time, in Figure 5 we outline the movement of unemployment and inflation over the review period. One can note the general downward trend of unemployment coinciding with a general rise in the inflation rate. Of particular interest, however, is the apparent acceleration in inflation following the Brexit vote, as indicated by the relatively steeper rise in slope of the inflation line to the right side of the Brexit referendum date (red dashed line).

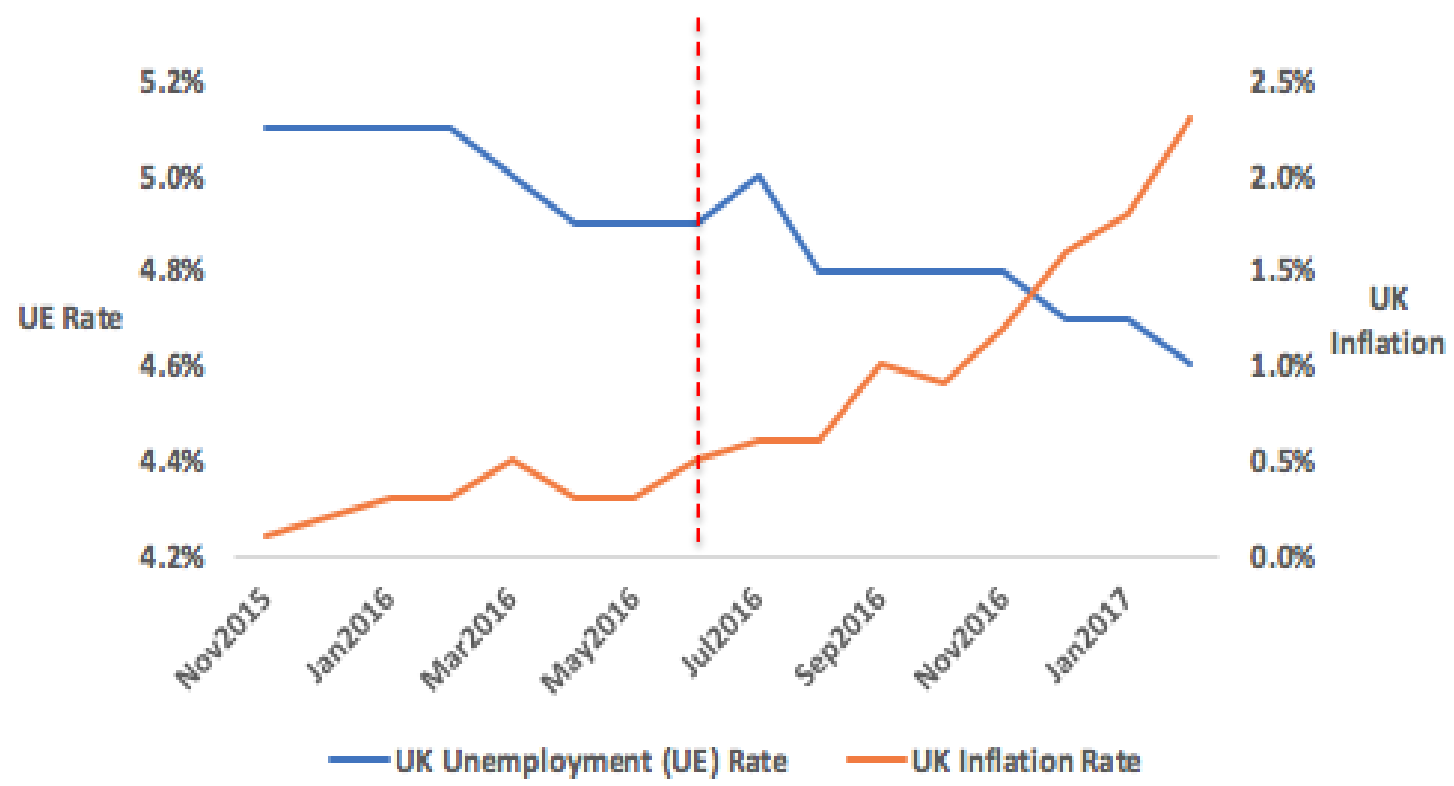

Figure 5. UK unemployment and UK inflation rate trends (Sept. 2015-Feb. 2017)

The final stage of our hypothesis assessment is to analyze UK immigration data and gauge the extent net migration into UK has changed, or not, post Brexit, and consider how any change may have impacted the UK labor markets in terms of employment and wage levels.

In May 2017, the ONS published the latest Migration Statistics Quarterly Report (MSQR) in collaboration with the UK Home Office and Department of Work and Pensions. The MSQR provides estimates of the number of migrants entering the UK minus the number of migrants leaving the UK for a given quarter ("net migration"). Additionally, the report details the country of migrant origin/return as well as the reason for migration. As such, this is a useful report to assess how the Brexit vote has impacted migration.

To begin we have reviewed the level of net migration both pre- and post-Brexit. As noted in Figure 6 following almost 5 years of net migration growth, which includes the impact of EU8 countries achieving free movement within the EU from May 2011, there has been a convergence in the number of migrants and emigrants in the latter half of 2016. EU8 nations comprise Latvia, Poland, Czech Republic, Slovakia, Hungary, Malta, Cyprus and Slovenia. Whilst total net migration levels had been relatively flat leading up to the Brexit vote, this convergence demonstrates a clear reduction in net migration following the UK vote to leave the EU.

Interestingly, upon further review of the MSQR and supporting data we note that the fall in net migration was "driven by a statistically significant increase in emigration", which was mostly attributable to EU citizens, being 117,000 emigrants in December 2016 versus 86,000 in December 2015) and the highest level of emigration recorded for this group in the entire dataset as shown in Table 3.

Of the 62,000 person reduction in immigration since June 2016 (month of EU Referendum), citizens from the EU8 countries accounted for a statistically significant portion, down from 73,000 to 48,000 (-34\%). Emigration figures for EU8 citizens also rose nearly $59 \%$ to 43,000 and "resulted in the smallest net migration $(+5,000$ per quarter) for the EU8 since joining the EU in 2004" (MSQR 2017) whereby the average net migration since 2009 has been approximately 39,000 per quarter. 
Table 3. UK immigration, emigration and net migration during December 2009 - December 2016 ('000s Individuals)

\begin{tabular}{cccc}
\hline Date & $\begin{array}{c}\text { UK } \\
\text { Immigration }\end{array}$ & $\begin{array}{c}\text { UK } \\
\text { Emigration }\end{array}$ & $\begin{array}{c}\text { Net UK } \\
\text { Migration }\end{array}$ \\
\hline Dec 2009 & 567 & 368 & 199 \\
Mar 2010 & 587 & 365 & 222 \\
Jun 2010 & 582 & 347 & 235 \\
Sep 2010 & 600 & 345 & 255 \\
Dec 2010 & 591 & 339 & 252 \\
Mar 2011 & 578 & 336 & 242 \\
Jun 2011 & 589 & 342 & 247 \\
Sep 2011 & 581 & 339 & 242 \\
Dec 2011 & 566 & 351 & 215 \\
Mar 2012 & 536 & 352 & 184 \\
Jun 2012 & 517 & 349 & 168 \\
Sep 2012 & 497 & 343 & 154 \\
Dec 2012 & 498 & 321 & 177 \\
Mar 2013 & 493 & 318 & 175 \\
Jun 2013 & 502 & 320 & 182 \\
Sep 2013 & 530 & 320 & 210 \\
Dec 2013 & 526 & 317 & 209 \\
Mar 2014 & 552 & 316 & 236 \\
Jun 2014 & 574 & 320 & 254 \\
Sep 2014 & 615 & 323 & 292 \\
Dec 2014 & 632 & 319 & 313 \\
Mar 2015 & 644 & 308 & 336 \\
Jun 2015 & 639 & 303 & 336 \\
Sep 2015 & 619 & 297 & 322 \\
Dec 2015 & 631 & 299 & 332 \\
Mar 2016 & 635 & 309 & 326 \\
Jun 2016 & 650 & 315 & 335 \\
Sep 2016 & 596 & 339 & 273 \\
Dec 2016 & 588 & & \\
\hline
\end{tabular}

Of all individuals migrating into the UK in 2016, work remained the key reason for immigration. 180,000 immigrants already had a definite job and 95,000 individuals immigrated in search of a job, which may appear high however this figure is 35,000 lower than 2015 and is reported in the MSQR as being a statistically significant decline. 


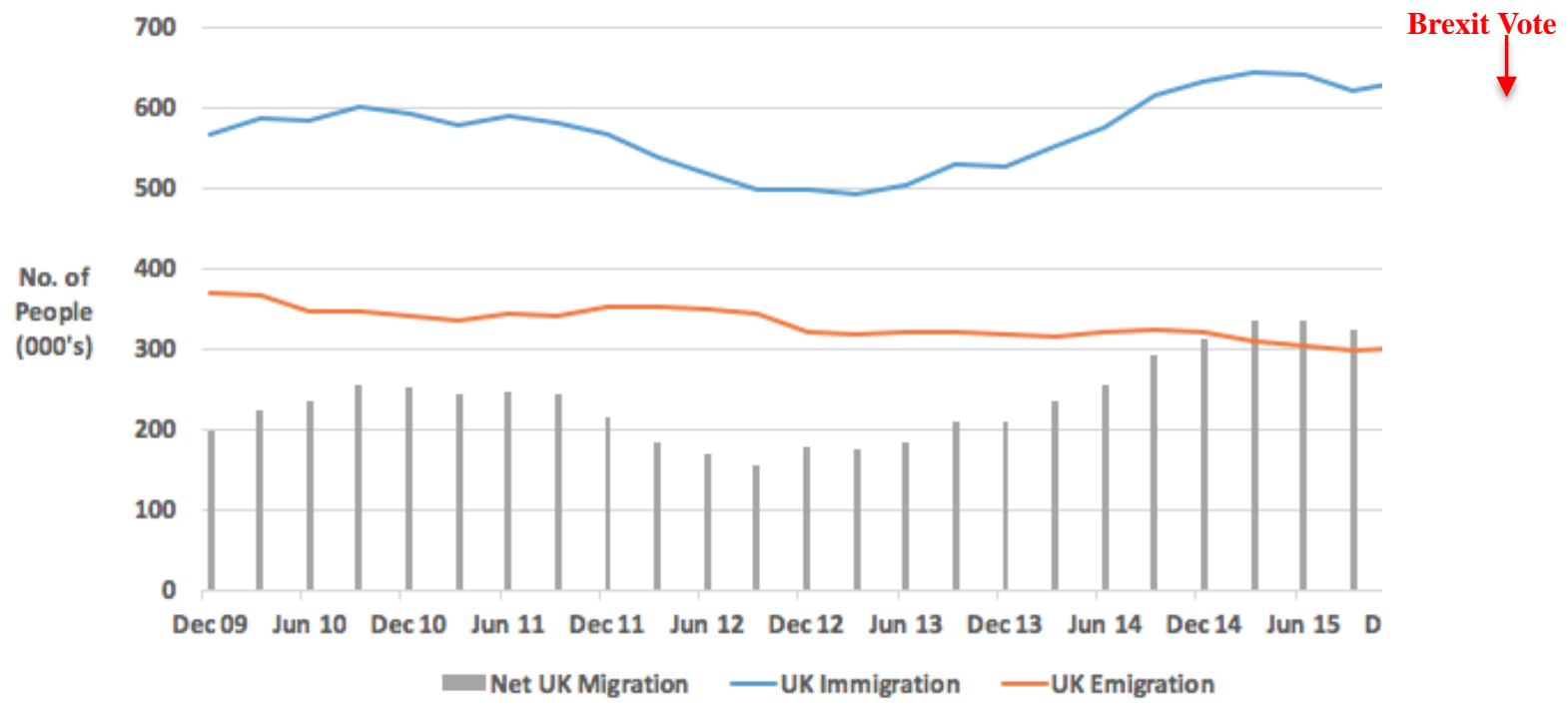

Figure 6. UK immigration, emigration and net migration trends (Dec. 2009 - Dec. 2016)

To summarize, whilst still early days post the EU referendum and despite some ambiguity regarding the extent of UK immigration policy, the 2017 MSQR provides interesting initial data to suggest that EU citizens, and especially those from the EU8 nations, have reacted to the Brexit vote by re-evaluating plans to remain in the UK or to relocate to the UK. The decision to leave the EU appears to have sent a major signal. Not only does Brexit indicate it is going to be more difficult to find a job, relocate family to the UK and claim work related benefits, the future of those EU citizens already established in the UK also remains uncertain. Figure 6 provides evidence to suggest that certainty elsewhere is more attractive than the uncertainty of remaining in the UK. As such, the 2017 MSQR supports our hypothesis that the UK Brexit vote has kick started a reduction in net migration and, more specifically, a reduction in EU citizens seeking or continuing to work in the United Kingdom. As such, with existing workers leaving and fewer potential workers arriving into the UK, the net effect is a contraction in the UK labor supply, thus, facilitating a reduction in the UK unemployment rate, supporting $\mathrm{H} 3$.

We believe the UK has started to feel the impact of the labor supply contraction since the Brexit vote, not only via a reduction in unemployment, but also through increased inflation. Furthermore, we believe the change in unemployment and inflation rates are linked (Figure 5). We believe UK Monetary Policy decisions post the 'shock' Brexit vote have helped businesses to absorb and afford wage growth and are an effort to boost economic activity. The UK Monetary Policy Committee responded to the Brexit vote by introducing an interest rate cut, a new scheme to encourage commercial banks to pass on lower borrowing costs and $£ 70 \mathrm{bn}$ worth of quantitative easing (Guardian, Aug 2016).

Finally, taking analysis of our results one step further we assert that the rise in UK inflation relative to the EU has influenced, and will continue to influence the $€ / £$ exchange rate as this inflation rate differential changes. More specifically, we believe, through our demonstration of PPP and spot rate alignment, that the rising inflation differential between the UK and EU has played a key role in the directional change of the $€ / £$ spot rate and depreciation of the pound since the announcement of Britain's vote to leave the EU.

\section{Conclusion and Discussion}

The key focus of this study has been to explore the effect that relative changes in inflation rates, prompted by Brexit policy, can have on $€ / £$ exchange rates. There are certainly other factors which influence exchange rates, be it the supply and demand requirements aligned to a country's balance of trade, the extent of political instability as well the general economic performance of a nation relative to others. That we have not removed the effects of these factors in order to isolate the effects only of inflation is a limitation of this paper. For example, we have already alluded to the Brexit vote raising uncertainty regarding major economic matters such as future terms of foreign trade, and that the uncertainty surrounding the UK general election has fueled political instability in the UK. And whilst these factors are likely to have contributed to the post-Brexit depreciation of the pound to some extent, we nevertheless believe we have made a solid argument to demonstrate that the protectionist nature of Brexit policy has had an immediate impact on net 
migration with consequences of rising inflation which has a been key contributor to the decline of the British pound value.

As previously stated, the purpose of this paper is not to confirm the exact portion of British pound depreciation solely due to a rising inflation differential, rather it is to demonstrate, with the support of credible theory and evaluation of relevant metrics, a link between Brexit policy, inflation and the subsequent directional change in the $€ / £$ exchange rate. Furthermore, in the absence of agreed exit terms, we cannot know with certainty how severe, or not, the terms of trade will be for the UK going forward nor when new terms will commence. As such, the balance of trade impact is not certain and, perhaps, is not/cannot be correctly priced into the value of the pound at present. A core message from the Brexit "yes" vote is certain, however, and the intentions of the UK government regarding immigration controls is clear. EU citizens have reacted and adjusted their business practices and personal situations in response to the vote, which has had immediate and notable repercussions for the British labor market, inflation and subsequent exchange rates.

Where does the British pound go from here? By end of summer 2017, the future governing political party of the UK is expected to be known, whose manifesto and general public perception may pose implications for the value of the pound. The general election result could even prompt a Brexit re-vote, thus the future of UK international trade agreements, and whether the tougher immigration stance will be reversed remains far from clear. Whilst the falling pound is welcomed by UK exporters, the reverse is true for UK importers. That the UK is a nation with a widening net-import position (Figure 7) rising to $£ 14.3 \mathrm{~B}(\$ 18.4 \mathrm{~B})$ raises concern. As a depreciating pound makes imports more expensive, there is a very credible threat of further inflation and currency depreciation if rising import costs are passed on to consumers.

Furthermore, if trade negotiations with the EU prove unfavorable the risk of accelerated inflation rises further should import tariffs, for example, replace the current free movement of goods and services. With inflation at $2.3 \%$, it is already above the UK Monetary Policy Committee (MPC) target of $2 \%$ and has real potential to rise further. A key challenge for the MPC is to balance the return of inflation to its target, whilst also supporting real output growth. As succinctly explained by the MPC in their December 2016 policy summary "the lower level of sterling [British Pound] since the vote to leave the European Union has adversely affected that trade-off'. Thus, managing inflation, currency valuation and maintaining economic growth is not an easy task ahead for the MPC.

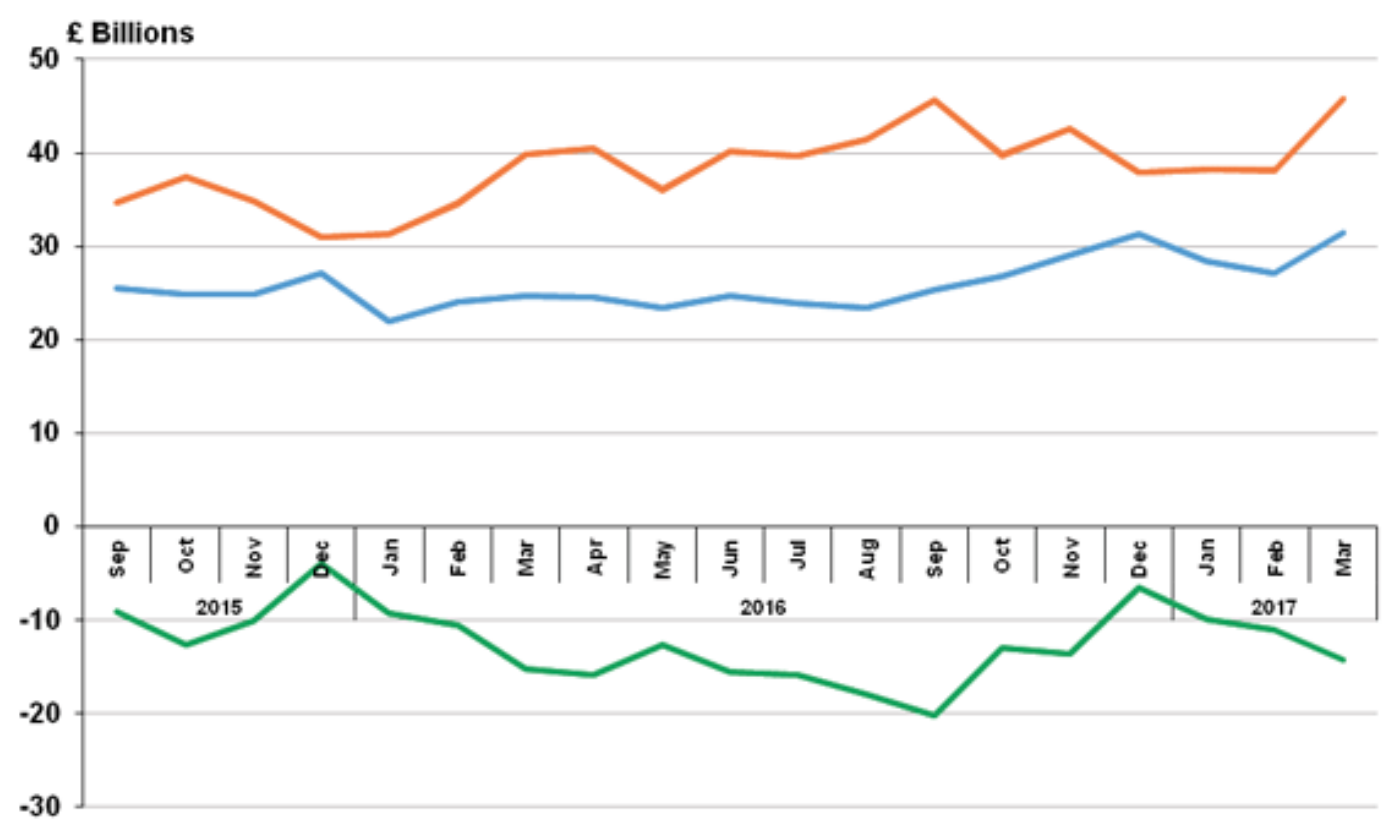

Source: HM Revenue \& Customs Orerseas Trade Statistics Note: 2016 and 2017 data is provisional

Figure 7. UK imports, exports and net import position trend 
Nevertheless, significant support for Brexit remains. The UK is surely not at the mercy of the EU nations, is it? And is expected to have power to bring to the EU exit negotiating table. Clearly, there is still a long way to go and agreements to be made and understood before greater clarity regarding the full consequences of Brexit can be achieved. The research presented and consideration of further inflationary pressures ahead do, however, provide some background for thought for policy-makers, investors and FX traders regarding the social and financial implications of Brexit, as well as for academics by way of potential areas for extension to this study.

\section{References}

Abuaf, N., \& Jorion, P. (1990). Purchasing power parity in the long run. Journal of Finance, 45, 157-174. http://dx.doi.org/10.1111/j.1540-6261.1990.tb05085.x

Adler, M., \& Lehman, B. (1983). Deviations from purchasing power parity in the long run. Journal of Finance, 45, 157-174. http://dx.doi.org/10.1111/j.1540-6261.1983.tb03835.x

Aliber, R. (1973). The interest rate parity theorem: A reinterpretation. Journal of Political Economy, 1451-1459. http://dx.doi.org/10.1086/260137

Bank of England. (2016, December). "Monetary policy summary" Minutes from 15 December 2016 Meeting.

Brücker, H., Jahn, E., \& Upward, R. (2012). Migration and imperfect labor markets: Theory and cross-country evidence from Denmark, Germany and the UK. Norface Migration. Discussion Paper No. 2012-20.

Cassel, G. (1918, December). Abnormal deviations in international exchanges. Economic Journal, 28(112), 413-415.

Chen, Y., \& Tsang, K. (2013). What does the yield curve tell us about exchange rate predictability? Review of Economics and Statistics, 95(1), 185-205. http://dx.doi.org/10.1162/REST_a_00231

Dornbusch, R., \& Krugman, P. (1976). Flexible exchange rates in the short run. Brookings Papers on Economic Activity, 1(3), 537-75.

Fouda. R. (2012, October). Protectionism and free trade: A country's glory or doom? International Journal of Trade, Economics and Finance, 3(5).

Frenkel, J. (1979). On the Mark: A theory of floating exchange rates based on real interest differentials. American Economic Review, 69, 610-622.

Frenkel, J. (1981a). Flexible exchange rates, prices and the role of news: lessons from 1970s. Journal of Political Economy, 89, 665-705. http://dx.doi.org/10.1086/260998

Frenkel, J. (1981b). The collapse of purchasing power parities during the 1970s. NBER, and the University of Chicago, IL.

Giddy, I., \& Dufey, G. (1975). The random behavior of flexible exchange rates. Journal of International Business Studies, 1-32. http://dx.doi.org/10.1057/palgrave.jibs.8490765

Gruben, W., \& Mcleod, D. (2004). The openness-inflation puzzle revisited. Applied Economics Letters, Taylor \& Francis Journals, 11(8), 465-468.

Guardian. (2016). This is the Bank of England's All-Action Response. Retrieved from https://www.theguardian.com/business/2016/aug/04/bank-of-england-all-action-response-brexit-qe-interest-rate -cut

Hakkio, C. (1992). Is purchasing power parity a useful guide to the Dollar? Federal Reserve Bank of Kansas, 37-51.

Investopedia. Protectionism. Retrieved from http://investopedia.com/terms/p/protectionism. asp£ixzz4hOq58c8Z

Jo, H., Dixon, J., Masubuchi, T., Parmar, M., \& Rastogi, S. (2016). International parity relations and economic shock: Evidence from Swiss Franc unpegging. International Journal of Financial Research, 7, 1-13. http://dx.doi.org/10.5430/ijfr.v7n4p1

Meese, R., \& Rogoff, K. (1988). Was it real? The exchange rate interest rate differential relation over the modern floating rate period. Journal of Finance, 43, 933-948. http://dx.doi.org/10.1111/j.1540-6261.1988.tb02613.x

Nobile, N., \& Skarica, B. (2016, January). Revisiting the Eurozone Phillips curve. United Kingdom Economic Outlook, 40(1), 28-36.

Office for Nation Statistics, (2017). Migration Statistics Quarterly Report: May 2017. London: Office for National Statistics. 
Phillips, A. W. (1958). The relation between unemployment and the rate of change of monetary wages in the United Kingdom, 1861-1957. Economica, 25, 283-299. https://doi.org/10.1111/j.1468-0335.1958.tb00003.x

Rogoff, K. (1996). The purchasing power parity puzzle. Journal of Economic Literature. 34(2), 647-68.

Romer, D. (1993). Openness and inflation: Theory and evidence. Quarterly Journal of Economics, 108(4), 869-903. https://doi.org/10.2307/2118453

Samuelson, P.A., \& Solow, R. M. (1960). Analytical aspects of anti-inflation policy. American Economic Review Papers and Proceedings, 50(2), 177-94.

Taylor, A., \& Taylor, M. (2004). The purchasing power parity debate. Journal of Economic Perspectives, 18(4), Fall, 135-158. https://doi.org/10.3386/w10607

Temple, J. (2002). Openness, inflation, and the Phillips curve: A puzzle. Journal of Money, Credit and Banking. 34(2), 450-468. https://doi.org/10.1353/mcb.2002.0049

\section{Data Sources}

Spot-Rates:

http://www.bankofengland.co.uk/boeapps/iadb/index.asp?Travel=NIxSTxTIx\&levels=1\&XNotes=Y\&A3801XBMX 3790X3791.x=5\&A3801XBMX3790X3791. $y=7 \& X N o t e s 2=Y \&$ Nodes $=X 3790 X 3791 X 3873 X 33940 \&$ SectionRequir ed=I\&HideNums=-1\&ExtraInfo=false\#BM

Inflation Rates:

UK - https://www.ons.gov.uk/economy/inflationandpriceindices/datasets/consumerpriceinflation

EU - https://www.statbureau.org/en/eurozone/inflation

LIBOR Rates:

UK (GBP) - https://fred.stlouisfed.org/series/GBPONTD156N

EURO - https://fred.stlouisfed.org/series/EURONTD156N

UK Unemployment:

https://www.ons.gov.uk/employmentandlabourmarket/peoplenotinwork/unemployment/timeseries/mgsx/lms

UK Net Migration:

https://www.ons.gov.uk/peoplepopulationandcommunity/populationandmigration/internationalmigration/datasets/mi grationstatisticsquarterlyreportprovisionallongterminternationalmigrationltimestimates

UK International Trade / Net Import Position:

https://www.uktradeinfo.com/Statistics/OverseasTradeStatistics/Pages/OTS.aspx

\section{Notes}

Note 1. EU referendum Results obtained from https://www.bloomberg.com/graphics/2016-brexit-referendum/

Note 2. http://www.bbc.com/news/uk-politics-32695399

Note 3.

https://www.theguardian.com/business/2016/jun/23/british-pound-given-boost-by-projected-remain-win-in-eu-refere ndum 